\title{
Nutrition and bioactive potential of the noni fruit cultivated from the Mato Grosso State
}

\author{
Ilmara Pereira de Vasconcelos $^{1}$ (i) Rodrigo Esaú Vassoler Silva ${ }^{1}$ (i) \\ Patrícia Monique Crivelari Costa ${ }^{2^{*}}$ (D) Luiz José Rodrigues ${ }^{1}$ (D)
}

${ }^{1}$ Departamento de Alimentos e Nutrição, Faculdade de Nutrição, Universidade Federal de Mato Grosso (UFMT), Cuiabá, MT, Brasil. ${ }^{2}$ Departamento de Agronomia, Faculdade de Ciências Biológicas e Agrárias, Universidade do Estado de Mato Grosso (UNEMAT), 78580-000, Alta Floresta, MT, Brasil. E-mail: patriciacrivellari@gmail.com. *Corresponding author.

ABSTRACT: The objective was to evaluate the physical and chemical characteristics of noni (Morinda citrifolia) grown in the Mato Grosso State. Ripe fruits from a field located in Cuiabá-MT, had the peel, pulp and seeds separated and subjected to different evaluations. The fruit parts were characterized physically and chemically. Determinations of vitamin $C$, carotenoids, phenolics and the total antioxidant activity of the fruit mesocarp (pulp) were made. Noni cultivated in the Mato Grosso State presents high levels of potassium, calcium and sodium, with predominance of potassium. The protein content was higher in the seed, and the ash, in the peel, respectively. Noni pulp showed high levels of vitamin $C$, carotenoids and phenolics and can be considered a potential antioxidant.

Key words: Morinda citrifolia, characterization, phytonutrients, antioxidant activity.

Potencial nutricional e bioativo do noni cultivado no estado de Mato Grosso

RESUMO: Objetivou-se avaliar as características físicas e químicas do noni (Morinda citrifolia) cultivado no estado de Mato Grosso. Frutos maduros provenientes de um plantio localizado na cidade de Cuiabá, MT, tiveram a casca, polpa e as sementes separadas e submetidas a diferentes avaliações. As partes das frutas foram caracterizadas física e quimicamente. Foram feitas determinações de vitamina $C$, de carotenoides, de fenólicos e da atividade antioxidante total do mesocarpo (polpa) do fruto. O noni cultivado no Mato Grosso apresenta altos níveis de potássio, cálcio e sódio, com predominância de potássio. O teor de proteína foi maior na semente e, de cinzas, na casca, respectivamente. A polpa de noni apresentou altos níveis de vitamina C, carotenoides e fenólicos e pode ser considerado um potencial antioxidante.

Palavras-chave: Morinda citrifolia, caracterização, fitonutrientes, atividade antioxidante.

\section{INTRODUCTION}

The species Morinda citrifolia (Rubiaceae family), known as noni, has origin in Southeast Asia and some areas of Australia and Pacific Islands. The fruit is traditionally used as a popular medicine against diseases such as diabetes, hypertension and cancer (ALI et al., 2016). Among the natural antioxidants in fruits that have received most attention is vitamins $\mathrm{C}$, carotenoids and phenolics, mainly because these compounds are capable of inhibiting oxidation, reducing the concentration of free radicals (PIENIZ et al., 2009).

The commercial appeal of supposed pharmacological properties associated with noni has significantly contributed to the fruit diffusion in Brazil (CORREIA et al., 2011; SILVA et al., 2012; COSTA et al., 2013). Thus, the characterization of the nutritional value of the fruit becomes important, since the nutritional requirements of the human being are met from a balanced diet, and the dietary balance is based on the knowledge of its chemical composition.

However, information about the nutritional potential of $M$. citrifolia is limited, especially fruit grown in the Mato Grosso State, which suggests the need for scientific investments (FARIA et al., 2014; FARIAS et al., 2018). Thus, the objective was the physical and chemical characterization of noni (Morinda citrifolia) epicarp (peel), mesocarp (pulp) and seeds cultivated in Cuiabá city, Mato Grosso State, as well as 
determinations of vitamin $\mathrm{C}$, carotenoids, phenolics and total antioxidant activity of the mesocarp.

Noni fruits (Morinda Citrofolia) from an orchard located in the Cuiabá city, Mato Grosso State, Brazil (176.8 masl; coordinate of $15^{\circ} 35^{\prime} 46^{\prime \prime} \mathrm{S}$ and $56^{\circ} 05^{\prime} 48^{\prime \prime} \mathrm{W}$ ) were harvested in a commercial plantation area in August 2013 at the mature stage (whitish yellow peel color and easily absent from the mother plant). According to the Köppen classification, the climate of this region is AW, characterized as hot and humid tropical, with annual average rainfall and temperature of $1,750 \mathrm{~mm}$ and $24^{\circ} \mathrm{C}$, respectively. The material was collected in the morning and transported to the Food Technology Laboratory of the Faculty of Nutrition (FANUT) of the Federal University of Mato Grosso (UFMT), in a total of 100 fruits, collected from different plants. The experiment consisted of 10 repetitions, with 10 ripe fruits. The fruits were selected for color uniformity, health and absence of injuries and defects, and then washed with neutral detergent and running water to remove surface dirt from the field. The peel, pulp and seeds were manually separated and grinded in a domestic multiprocessor and immediately placed in polyethylene bags. It was stored in a freezer at $-18{ }^{\circ} \mathrm{C}$, for later analysis.

Fresh mass (g) was evaluated by weighing each fruit individually on a semi-analytical balance, and then peel, pulp and seeds were weighed separately. Longitudinal and transverse diameter (cm) were performed using a manual caliper rule. Peel, pulp and seeds fractions in relation to whole fruit were obtained as a percentage $(\%)$. The firmness (N) was determined at three random points of the fruits with the aid of a Stable Micro System model TA.XT plus texturometer, using a $\mathrm{P} / 2$ needle probe ( $2 \mathrm{~mm}$ diameter), which measured the force of fruit penetration at a speed of $5 \mathrm{~mm} \cdot \mathrm{s}^{-1}$ and a distance of $5 \mathrm{~mm}$. The color was determined with the aid of the Minolta CR-400 colorimeter with D65 illuminant and the CIE $\mathrm{L}^{*} \mathrm{a}^{*} \mathrm{~b}^{*}$ system. The readings of the values $L^{*}, a^{*}$ and $b^{*}$ were taken at three random points of the fruit peel.

The centesimal composition (\%) were performed according to the AOAC (2005). Calcium, magnesium, copper, manganese, zinc and iron (mg.100g-1) determinations were performed, made by atomicabsorption spectrophotometryusingaSpectrAA 110 (Varian INE) model apparatus calibrated under specific wavelength, slit and gas mixture conditions for each element. Phosphorus (mg.100 $\left.\mathrm{g}^{-1}\right)$ was analyzed by UV/Vis spectrophotometry on a Perkin Elmer Lambida $25 \mathrm{UV} /$ Vis apparatus. Potassium and sodium (mg.100 $\left.\mathrm{g}^{-1}\right)$ determinations were performed by flame emission photometry in a Micronal B-262 apparatus. For all analyzes, the procedures described by MALAVOLTA et al. (1989). Titratable acidity (\% citric acid) was performed by titration with $0.1 \mathrm{~N} \mathrm{NaOH}$ solution using phenolphthalein as an indicator. The $\mathrm{pH}$ was determined using a TeKna $\mathrm{pH}$ meter (T-1000) according to AOAC (2005). Soluble Solids (\%) were determined by refractometry using a Quimis manual refractometer without temperature compensation (AOAC, 2005).

Ascorbic acid content (mg.100g $\left.\mathrm{g}^{-1}\right)$ (after oxidation to dehydroascorbic acid) was determined by the colorimetric method using 2,4 dinitrophenylhydrazine according to STROHECKER \& HENNING (1967). Total carotenoid content $\left(\mathrm{mg} .100 \mathrm{~g}^{-1}\right)$ was determined according to AOAC (2005) and adapted by COSTA el al. (2013). Extracts were prepared from $10 \mathrm{~g}$ of ground cellulose sample with $85 \mathrm{~mL}$ of distilled water in an Erlenmeyer. Then, the sample was solved from three solvents: water, ethanol and acetone. For each solvent, except for water, $40 \mathrm{ml}$ of each mixture, that is, ethanol and acetone, were added separately. The mixture was homogenized for 1 hour, in Erlenmeyer flasks, using the magnetic stirrer. The solution was transferred to a separating funnel. After 30 minutes of rest, $10 \mathrm{ml}$ of distilled water was added and then the mixture was filtered. These extracts were read in triplicate using a spectrophotometer (Coleman $33 \mathrm{D}$ ) at $450 \mathrm{~nm}$.

Total phenolic content (mg. $100 \mathrm{~g}^{-1}$ gallic acid equivalents) of the extracts was measured using Folin-Denis reagent (SWAIN \& HILLS, 1959); first, either $0.5 \mathrm{~mL}$ of the extract, or an appropriate gallic acid standard, was added to $8.0 \mathrm{~mL}$ deionized water; to this, $0.5 \mathrm{~mL}$ of Folin-Denis reagent and $1 \mathrm{~mL}$ of saturated $\mathrm{Na}_{2} \mathrm{CO}_{3}$ solution was added and mixed for $3 \mathrm{~min}$ and after incubation for $60 \mathrm{~min}$, absorbance was measured at $720 \mathrm{~nm}$. Total antioxidant activity $\left(\mathrm{IC}_{50} \mu \mathrm{g} \cdot \mathrm{mL}^{-1}\right)$ was evaluated by the 2,2-diphenyl1-picrylhydrazyl method (SCHERER \& GODOY, 2009). The data obtained were submitted to descriptive statistical analysis. The arithmetic mean and standard deviation were calculated.

The average fresh mass of ripe fruit was $58.3 \mathrm{~g}$, with the peel, pulp and seeds representing 20.13, 49.62 and $30.25 \%$ of their total weight, respectively. The longitudinal and transverse diameter of noni presented average values of 10.8 and $8.4 \mathrm{~cm}$, respectively. SILVA et al. (2012) observed proportional values; however, smaller. They observed fresh mass values of $51.19 \mathrm{~g}$ and longitudinal and transverse diameter of 10.4 and $7.9 \mathrm{~cm}$, respectively. The firmness of mature noni was $16.36 \mathrm{~N}$. The firmness represents one of the most 
important physical characteristics, since fruits with high firmness suggested a longer postharvest shelf life.

The coordinates $\mathrm{L}^{*}, \mathrm{a}^{*}$ and $\mathrm{b}^{*}$ of noni peel presented average values of $68.76 ;-2.71$ and 38.62 , respectively. Fruits tend to increase the value of the $\mathrm{L}^{*}$ and $\mathrm{a}^{*}$ due to the loss of green color, due to chlorophyll degradation. As it ripens, the fruit gradually changes its color from dark to light green (CHITARRA \& CHITARRA, 2005).

Water is the most abundant component in noni, with average moisture contents of $86.63 \%$ (Table 1). FARIAS et al. (2018) showed moisture values for the peel $(84.89 \%)$ and pulp $(89.55 \%)$ of noni cultivated in Arenápolis-MT, close to those reported in this research. However, FARIA et al. (2014) reported higher mean values for the pulp moisture, of $90.66 \%$, to Cuiabá-MT. The mean lipid, protein and ash contents was of $0.25 \%, 1.22 \%$ and $0.96 \%$, respectively (Table 1 ). FARIAS et al. (2018) found protein and ashes values of $0.96 \%$ and $0.87 \%$, for the peel, and, of $1.26 \%$ and $0.69 \%$, for the pulp, respectively, of noni cultivated in Arenápolis-MT. It was indicated that these authors have higher protein content and lower ashes than this present Research. They did not study about lipid content. FARIA et al. (2014) reported mean values for the lipid, protein and ash content of $0.04 \%, 2.36 \%$ and $0.66 \%$ for the pulp of noni fruits cultivated in Cuiabá-MT, with only the protein contend higher than this present research
The glycidic fraction, represented by the carbohydrate portion, presented mean values of $11.94 \%$ in the noni grown in Mato Grosso State (Table 1). FARIA et al. (2014) found mean values for the carbohydrate of $8.98 \%$ in the pulp, lower than this work. Based on the caloric value, noni presented mean of $50.92 \mathrm{kcal}$, with the major proportion in the seed (Table 1). Caloric values were not reported in noni fruits from Mato Grosso State. To noni fruit, it was found for the peel, pulp and seeds, respectively, values of $52.40,45.77$ and $124.53 \mathrm{kcal}$ from Piauí State (COSTA et al., 2013); 11.52 and 43.23 kcal for the pulp and seeds from Maranhão State (NASCIMENTO et al., 2018), and; $30.25 \mathrm{kcal}$ for the pulp from Ceará State (CORREIA et al., 2011). Proportionally, closest values are seen in the Piaui State; however, values reported in Mato Grosso State differ from the other.

Among the analyzed minerals, potassium was the element with the highest content in the peel, pulp and seed, with mean of $72.97 \mathrm{mg} 100 \mathrm{~g}^{-1}$ in the integral noni fruit. Still, significant values for calcium and sodium were found in the different evaluated parts of the fruit. Other minerals analyzed, such as iron and copper, have reduced levels (Table 1). When related to other fruits, in the noni pulp cultivated in Mato Grosso State, the potassium contents were higher than the values of pineapple, guava, papaya, melon, strawberry and pear; the calcium levels were

Table 1 - Centesimal composition and mineral content in whole matter of epicarp (peel), mesocarp (pulp) and Noni seed (Morinda citrifolia) from Mato Grosso State.

\begin{tabular}{|c|c|c|c|}
\hline Composition & Peel & Pulp & Seed \\
\hline Moisture (\%) & $86.93 \pm 0.13^{*}$ & $89.53 \pm 0.15$ & $83.42 \pm 0.79$ \\
\hline Lipids (\%) & $0.18 \pm 0.06$ & $0.32 \pm 0.04$ & $0.26 \pm 0.09$ \\
\hline Protein $(\%)$ & $1.04 \pm 0.04$ & $0.76 \pm 0.05$ & $1.85 \pm 0.12$ \\
\hline Ashes (\%) & $1.26 \pm 0.04$ & $0.84 \pm 0.08$ & $0.78 \pm 0.05$ \\
\hline Glycid fraction (\%) & $10.59 \pm 0.04$ & $8.55 \pm 0.04$ & $13.69 \pm 0.04$ \\
\hline Calorific value (kcal) & $48.14 \pm 0.02$ & $40.12 \pm 0.02$ & $64.50 \pm 0.15$ \\
\hline Calcium (mg.100-1) & $8.70 \pm 0.06$ & $35.20 \pm 0.04$ & $22.60 \pm 0.06$ \\
\hline Potassium (mg.100-1) & $31.90 \pm 0.02$ & $241.00 \pm 0.11$ & $187.00 \pm 0.12$ \\
\hline Sodium $\left(\mathrm{mg} .100^{-1}\right)$ & $24.60 \pm 0.06$ & $19.40 \pm 0.04$ & $16.20 \pm 0.05$ \\
\hline Magnesium (mg.100-1) & $16.30 \pm 0.04$ & $12.20 \pm 0.09$ & $12.60 \pm 0.01$ \\
\hline Phosphorus (mg.100-1) & $28.40 \pm 0.02$ & $14.40 \pm 0.03$ & $15.10 \pm 0.01$ \\
\hline $\operatorname{Iron}\left(\mathrm{mg} \cdot 100^{-1}\right)$ & $2.36 \pm 0.05$ & $0.48 \pm 0.06$ & $0.19 \pm 0.01$ \\
\hline Cupper (mg.100-1) & $0.04 \pm 0.01$ & $0.09 \pm 0.01$ & $0.06 \pm 0.01$ \\
\hline Zinc (mg.100 $\left.100^{-1}\right)$ & $0.16 \pm 0.02$ & $1.17 \pm 0.01$ & $0.08 \pm 0.01$ \\
\hline Manganese (mg.100-1) & $3.49 \pm 0.01$ & $1.82 \pm 0.02$ & $1.38 \pm 0.02$ \\
\hline
\end{tabular}

*Mean values \pm standard deviation $(\mathrm{n}=10)$. 
lower than pineapple, acerola and papaya, and; the sodium were higher than the mango, passion fruit and melon (TACO, 2011). FARIA et al. (2014) found mean values for potassium and sodium of 50.13 and $19.76 \mathrm{mg} .100 \mathrm{~g}^{-1}$ in the pulp noni from CuiabáMT, being the latter similar to the result obtained. No deepen mineral analyzes were reported in fruits grown in the Mato Grosso State.

Titratable acidity, $\mathrm{pH}$, soluble solids and vitamin $\mathrm{C}$ content in noni pulp were $0.32 \%$ citric acid, 3.64, $6.8{ }^{\circ}$ Brix and $106.12 \mathrm{mg} .100 \mathrm{~g}^{-1}$, respectively (Table 2). FARIA et al. (2014) reported values of $0.44 \%$ citric acid, 3.54 and 9.2 Brix, respectively for of titratable acidity, $\mathrm{pH}$ and soluble solids the noni pulp from Cuiabá-MT, similar to that found except for the last value, which was lower in the present study. The soluble solids content is dependent on the ripening stage at which the fruit is harvested and generally increases during ripening by biosynthesis or polysaccharide degradation (CHITARRA \& CHITARRA, 2005). Even, other fruits, recognized as a source of vitamin $\mathrm{C}$, such as orange $\left(53.7 \mathrm{mg} .100 \mathrm{~g}^{-1}\right)$ and guava $\left(80.6 \mathrm{mg} .100 \mathrm{~g}^{-1}\right)$, have lower levels of this variable than those reported in noni pulp (TACO, 2011).

Carotenoids form one of the most widely found groups of natural pigments in nature. The total carotenoid value in noni pulp was $32.06 \mathrm{mg} .100 \mathrm{~g}^{-1}$ (Table 2). COSTA et al. (2013), chemically characterizing the noni pulp produced in Piauí State, reports carotenoid contents of $3.9 \mathrm{mg} .100 \mathrm{~g}^{-1}$, about eight times lower than the fruit grown in Mato Grosso State.
Phenolic compounds are among the most active and frequently present antioxidants in plants. Its consumption has been associated with protective effects against cardiovascular disease and cancer (ALI et al., 2016). In the extraction of phenolic compounds present in noni pulp, the acetonic extract was more efficient when compared to the ethanolic and aqueous extracts, with $94.81 \mathrm{mg} .100 \mathrm{~g}^{-1}$ (Table 2). FARIA et al. (2014) commented the presence of phenolics in pulp fruits from Mato Grosso, but no further research was reported in the State. COSTA et al. (2013) discuss the higher efficiency of acetone extract in the determination of phenols in noni pulp, with contents of this component of $109.8 \mathrm{mg} .100 \mathrm{~g}^{-1}$.

The total antioxidant activity of noni pulp was higher in aqueous extract, presenting $956.35 \mathrm{IC}_{50}$ $\mu$ g. $\mathrm{mL}^{-1}$ (Table 2). Several studies have emphasized the significant role of natural antioxidants in fruits, including vitamin $\mathrm{C}$, carotenoids and phenolic compounds. In view of the results, this research collaborated with the existing studies and may contribute to future more in-depth research on Noni in the Mato Grosso State.

Noni cultivated in the Mato Grosso State presents high levels of potassium, calcium and sodium, with predominance of potassium. The protein content was higher in the seed, and the ash, in the peel, respectively. Noni pulp showed high levels of vitamin $\mathrm{C}$, carotenoids and phenolics and can be considered a potential antioxidant.

Table 2 - Physical and chemical constituents and total antioxidant activity in mesocarp (pulp) of noni (Morinda citrifolia) from Mato Grosso State.

\begin{tabular}{|c|c|}
\hline Constituents & Mean \\
\hline $\mathrm{pH}$ & $3.64 \pm 0.05^{*}$ \\
\hline Titratable acidity (\% Citric acid) & $0.32 \pm 0.50$ \\
\hline Soluble solids ( $\left.{ }^{\circ} \mathrm{Brix}\right)$ & $6.80 \pm 0.02$ \\
\hline Vitamin C (mg. $100 \mathrm{~g}^{-1}$ Ascorbic acid) & $106.12 \pm 1.26$ \\
\hline Total carotenoids (mg. $100 \mathrm{~g}^{-1}$ ) & $32.06 \pm 0.78$ \\
\hline Phenolics & Mean \\
\hline Aqueous extract (mg.100g-1 $)$ & $12.63 \pm 1.02$ \\
\hline Ethanolic extract (mg. $\left.100 \mathrm{~g}^{-1}\right)$ & $18.09 \pm 1.51$ \\
\hline Acetone extract $\left(\mathrm{mg} \cdot 100 \mathrm{~g}^{-1}\right)$ & $94.81 \pm 0.89$ \\
\hline Antioxidant activity & Mean \\
\hline Aqueous extract $\left(\mathrm{IC}_{50} \mu \mathrm{g} \cdot \mathrm{mL}^{-1}\right)$ & $956.35 \pm 2.36$ \\
\hline Ethanolic extract $\left(\mathrm{IC}_{50} \mu \mathrm{g} \cdot \mathrm{mL}^{-1}\right)$ & $34.09 \pm 2.63$ \\
\hline Acetone extract $\left(\mathrm{IC}_{50} \mu \mathrm{g} \cdot \mathrm{mL}^{-1}\right)$ & $420.43 \pm 2.88$ \\
\hline
\end{tabular}

${ }^{*}$ Mean values \pm standard deviation $(\mathrm{n}=10)$. 


\section{ACKNOWLEDGEMENTS}

This study was funded by the Mato Grosso State Research Support Foundation (FAPEMAT - 157627/2014).

\section{DECLARATION OF CONFLICT OF INTERESTS}

The authors declare no conflict of interest. The founding sponsors had no role in the design of the study; in the collection, analyses, or interpretation of data; in the writing of the manuscript, and in the decision to publish the results.

\section{AUTHORS' CONTRIBUTIONS}

The authors also contributed to the manuscript.

\section{REFERÊNCIAS}

ALI, M. et al. Health Benefits of Morinda citrifolia (Noni): A Review. Pharmacognosy Journal, v.8, n.4, p.321-334 2016. Available from: <http://dx.doi.org/10.5530/pj.2016.4.4>. Accessed: Sep. 07, 2020. doi: 10.5530/pj.2016.4.4.

AOAC. Association of Official Agricultural Chemists. Official methods of the Association of the Agricultural Chemists. 17.ed. Washington, 2005. 1410p.

ChitarRa, M. I. F.; ChitarRa, A. B. Pós-colheita de frutos e hortaliças: fisiologia e manuseio. 2. ed. Lavras: FAEPE, 2005. 785p

CORREIA, A. A. S. et al. Chemical and physicalchemical characterization of noni pulp (Morinda citrifolia) grown in the Ceará State. Alimentos e Nutrição, v.22, n.4, p.609-615, 2011. Available from: < https://pdfs.semanticscholar.org/7520/75d9a0da 9643848459f9d5ecc1b95c9a61ab.pdf>. Accessed: Mar. 05, 2020.

COSTA, A.B. et al. Antioxidant activity of the pulp, skin and seeds of the Noni (Morinda citrifolia Linn.). Revista Brasileira de Fruticultura, v.35, n.2, p.345-354, 2013. Available from: $<$ https:// www.scielo.br/pdf/rbf/v35n2/03.pdf >. Accessed: Mar. 07, 2020.

FARIA, W. C. S. et al. Physicochemical characterization and preliminary phytochemical analysis of the Noni fuit (Morinda citrofolia L.) produced in Cuiabá city - MT. Revista Brasileira de Tecnologia Agroindustrial, v.8, n.1, p.1208-1215, 2014. Available from: <http://dx.doi.org/10.3895/S1981-36862014000100006>. Accessed: Jun. 08, 2020. doi: 10.3895/S1981-36862014000100006.

FARIAS, L. L. et al. Antimicrobial potential and physicochemical evaluation of noni shell, pulp and biomass (Morinda citrifolia Linn). Global Science and Technology, v.11, n.2, p.247-255, 2018. Available from: $<$ https://rv.ifgoiano.edu.br/periodicos/index php/gst/article/view/1011>. Accessed: Jun. 08, 2020

MALAVOLTA, E. et al. Avaliação do estado nutricional das plantas: princípios e aplicações. Piracicaba: POTAFOS, 1989. 201p.

NASCIMENTO, L. C. S. et al. Chemical characterization, nutritional aspects and antioxidant capacity of noni (Morinda citrifolia L) produced in northeastern Brazil. International Food Research Journal, v.25, n.2, p.870-875, 2018. Available from: $<$ https://www.ifrj.upm.edu.my/25\%20(02)\%202018/(58).pdf>. Accessed: Mar. 07, 2020

PIENIZ, S. et al. Avaliação in vitro do potencial antioxidante de frutas e hortaliças. Ciência e Agrotecnologia, v.33, n.2, p.552559, 2009. Available from: <http://dx.doi.org/10.1590/S141370542009000200030>. Accessed: Mar. 18, 2020. doi: 10.1590/ S1413-70542009000200030.

SCHERER, R.; GODOY, H. T. Antioxidant activity index (AAI) by the 2,2-diphenyl-1-picrylhydrazyl method. Food Chemistry, v.112, n.3, p.654-658, 2009. Available from: <http://dx.doi. org/10.1016/j.foodchem.2008.06.026>. Accessed: Mar. 18, 2020. doi: $10.1016 /$ j.foodchem.2008.06.026

SILVA, L. R. et al. Caracterização do fruto de noni (Morinda citrifolia L.). Revista Cubana de Plantas Medicinais, v.17, n.1, p.93-100, 2012. Available from: $<$ http://scielo.sld.cu/scielo. php?script $=$ sci arttext\&pid $=$ S1028-47962012000100010\&lng=es \&tlng=pt $>$. Accessed: Mar. 04, 2020.

STROHECKER, R.; HENNING, H. M. Analisis de vitaminas: metodos comprobados. Madrid: Paz Montalvo, 1967. 428p.

SWAIN, T.; HILLS, W. E. The phenolic constituents of Prunus domestica: the quantitative analysis of phenolic constituents. Journal of Science of Food and Agriculture, v.10, n.1, p.63-68, 1959. Available from: <http://dx.doi.org/10.1002/ jsfa.2740100110>. Accessed: Mar. 18, 2020. doi: 10.1002/ jsfa. 2740100110 .

TACO. Tabela Brasileira de Composição de Alimento. 2 version. Campinas: UNICAMP, 2011. Available from: <http:// www.unicamp.br/nepa/taco>. Accessed: Nov. 16, 2013. 